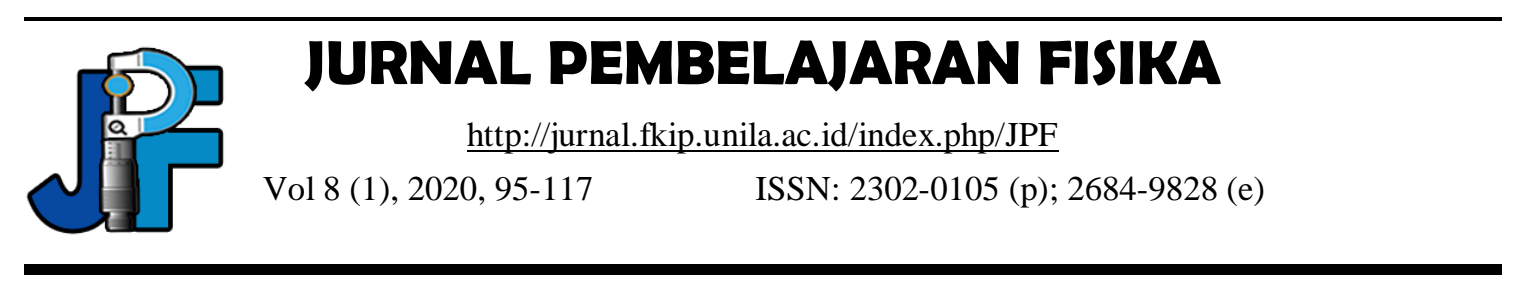

\title{
Assessing the Effectiveness of Contextual Based Learning Videos in Waves
}

\author{
Putri Bullquis Marsa ${ }^{1 *}$, Desnita ${ }^{1}$ \\ ${ }^{1}$ University of Padang, Indonesia \\ *e-mail: putribullquismarsa.a2@gmail.com
}

Received: April 18, 2020

Accepted: June 29, 2020

Published: June 30, 2020

\begin{abstract}
This study aims to produce a valid instrument in assessing the effectiveness of contextual video based wave material as an instructional medium of physics. The instrument consists of four sets; namely critical thinking skills instruments, creative thinking skills instruments, collaboration skills instruments, and communication skills instruments both oral and written. This research uses the type of development research. The development procedure consists of 10 stages. The instrument was validated by 2 experts. The validity category refers to the opinion of Aiken's $V$, where the value $\geq 0.6$ of the instrument is considered valid. To assess instrument validity the instrument validation assessment sheet was used. Based on the results of the instrument validation assessment conducted by the experts, it was found that all the instruments were considered valid with the average value of the critical thinking skills instrument of 0,91 , instruments of 0,93 , collaboration skills instruments of 0,99 , oral communication skills instruments of 0,98 , and written communication skills instruments of 0,90 . Thus all instruments can be used to validate the learning video that will be developed.
\end{abstract}

Keywords: Assessment, An instrument of effectiveness, Contextual, wave

DOI: http://dx.doi.org/10.23960/jpf.v8.n1.202010 


\section{INTRODUCTION}

The curriculum is one of the elements that makes a significant contribution to realizing the process of developing students' potential (Surahman, 2015). So there is no denying that a curriculum that is developed based on competence is needed as an instrument to direct students to become: (1) qualified human beings who are capable and proactive in responding to the challenges of the times which always change all the time; and (2) educated people who have faith and are devoted to God Almighty, have noble character, are in good health, knowledgeable, capable, creative and independent in life; and (3) citizens who are democratic and responsible in whatever they do (Tim Pengembang, 2012).

To catch up with the underdeveloped countries, the Government is always making changes and curriculum development. The Government's efforts to make changes related to the curriculum structure solely to improve the quality of education (Lestari, Mayub, \& Rohadi, 2017). Changes in the curriculum require adjustments in media, learning resources, and teaching materials used in learning. At present the media, learning resources, and teaching materials must be in accordance with the demands of 21 st century learning needs. This 21 st century can be seen and reviewed from the rapid development of information technology and the development of automation where many jobs that are routine and repetitive work are being replaced by machines, both production machines and computers (Wijaya, Sudjimat, \& Nyoto, 2016). Education is no exception. At present, education is in a period of knowledge with an accelerating increase in a variety of extraordinary knowledge. This is inseparable from the role of media and digital technology.

The use of information and communication technology is the main foundation of 21 st century learning. The development of information and communication technology that is very rapidly influencing the way of learning in the world of education, so that changes in the way of learning itself becomes inevitable, both by teachers and students (Yulianisa, Rizal, Oktaviani, \& Abdullah, 2018). In addition to using media, learning resources, and teaching materials, which are information and technology based, the learning process must also meet the learning needs of the 21 st century, namely learning that can enhance the $4 \mathrm{C}$ (critical thinking, creativity, communication, and collaboration) skills of students. In order for students' 4C skills to develop properly, students need to be familiarized with learning activities that practice the 4C skills themselves. Learning that can train 4C competencies is centered on students, teamwork, and learning related to the context of daily life (Prihadi, 2018). 21st century humans are also required to be independent learners (Zubaidah, 2018). In addition to having 4C skills, students must be able to use information and technology based media. The use of appropriate learning media can be an intermediary for students in learning, understanding, and deepening learning materials, and improving the quality of learning (Baharuddin, 2014).

The 2013 curriculum meets the learning needs of the 21st century. The 2013 curriculum follows and adapts to changes in science and technology, philosophy, psychology, and sociology (Festiyed, 2015). The 2013 curriculum makes learning centered on students (Aristiyaningsih \& Budiharti, 2015). In practice, students can practice 4C skills. The 2013 curriculum is a development of 2004 curriculum and improvements to 2006 curriculum (Haryadi, Sutrisno, \& Haratua, 2015). The 2013 
curriculum is a character and competency based curriculum which changes the pattern of education from an orientation to outcomes and materials to education as a process, through an integrative thematic approach with contextual (Rakhmawati, Muspiroh, \& Azmi, 2016). Students must be involved in the learning process so they can explore in order to form competencies by exploring various potentials in themselves, and scientific truth. The implementation of the 2013 curriculum requires a paradigm shift in learning from conventional learning that is only done in class to learning using a variety of learning resources that can be obtained by students outside the classroom (Pertiwi, Suyatna, \& Suyanto, 2019). Likewise in learning physics, which is physics which is a branch of science that studies natural phenomena and events, and reveals all the secrets and laws of nature (Khodizah, Irwandani, \& Kholid, 2019) must be able to involve many students and use various learning resources in the process the learning.

One of the concepts of learning in the 2013 Curriculum is contextual learning (Andiko, Rohiat, \& Elvinawati, 2019). Physics learning that is full of natural events and phenomena will be more meaningful if it is presented in contextual education. Contextual learning is learning that relates material to the real lives of students daily, both in the environment, family, school, community and citizens with the aim of discovering the meaning of the learning material for life (Komalasari, 2010). The learning process takes place naturally in the form of student activities that are working and experiencing, not the transfer of knowledge from teacher to student (Hanafiah \& Suhana, 2012).

Contextual learning has the following characteristics: 1) Learning is carried out in an authentic context, namely learning that guides students to be skilled in real life or learning carried out in a natural environment (learning in real life settings), 2) Learning provides opportunities to students to learn and make assignments that are meaningful (meaningful learning), 3) Learning is carried out by providing meaningful experiences to students (learning by doing), 4) Learning is carried out through work and discussions in, and mutual correction between friends (learning in a group), 5) Learning provides opportunities for students to create a sense of togetherness, working together, mutual understanding between one another deeply (learning to know each other deeply), 6) Learning is carried out both actively and creatively, and productively, and prioritize cooperation (learning to ask, to inquri, to work together), 7) Learning is carried out in pleasant situations (learning as an enjoy activity) (Mansur, 2011). Contextual learning also involves seven main components, as follows: (1) constructivism, (2) questioning, (3) inquiry, (4) learning community, (5) modeling, (6) ) reflection, and (7) authentic assessment (Rusman, 2012).

Contextual-based physics learning can be delivered using instructional media. The use of learning media has many benefits such as the learning process becoming more interesting, more interactive and the quality of learning of students can be improved (Arif, Festiyed, Desnita, \& Dewi, 2019). One of the learning media that is able to represent physics studies and is certainly in accordance with the demands of the 2013 curriculum, as well as meeting the learning needs of the 21 st century is learning videos. Video is one of the most dynamic and effective media in conveying information (Munir, 2013). The video presents a variety of information, explains the process of learning material, explains complex learning concepts, improves students' skills, shortens or extends the duration of time, and influences the attitude of students (Arsyad, 
2011). Video is an audio visual learning media that combines visual material and auditive material. Visual material makes students able to capture learning messages through visualization (observation) and auditive material makes students able to receive messages through hearing (Busyaeri, Udin, \& Zaenudin, 2016). Videos make it easy for students to learn abstract material and overcome the limitations of space and time. These advantages are the main attraction of students, learning becomes more concrete, not monotonous, not boring and finally able to increase students' understanding of a concept (Nurdin, et al, 2019).

To produce a true learning video in accordance with the needs of stakeholders, it is necessary to conduct a quality test covering validity, practicality, and effectiveness. Before quality testing is carried out, a quality instrument is needed to test the level of validity, practicality, and effectiveness of the video to be developed. By producing quality instruments, it is expected that the learning videos produced are also of high quality. The instrument has a very important role. Because with the presence of instruments, the quality of a study can be known. If the instruments are made, have good criteria, then the quality of the research is also good, and vice versa (Arifin, 2017). The instrument assesses the quality of contextual-based learning videos is done in order to produce quality videos so that when presented in the learning process can improve students' critical thinking skills, collaboration, and communication.

To get quality instruments scientific steps need to be taken. This article only explains the validity test of the effectiveness instrument because the effectiveness of a learning video is adjusted to the material presented with the video which is wave material, which is a very specific part of the research conducted. In this study, the effectiveness of contextual-based learning videos is measured by critical thinking, creative, collaboration, and communication skills for wave material.

Before the instrument assesses the quality of the learning video, the instrument is validated first. The purpose of instrument validation is to find out whether the instrument is feasible or not suitable for use (Adib, 2017). The validity of an instrument is very important in measurement activities, because with good measurements, a study will provide representative results (Yuniarti \& Soenarto, 2016).

This research is important to solve the problem of the need for a valid instrument to determine the quality of contextual-based learning videos.

\section{METHOD}

\section{Research Design \& Procedures}

This type of research is research and development. Research development is a research method used to produce educational products, and test the effectiveness of these products (Sugiyono, 2017).

The research development method used in this study refers to the method developed by Borg and Gall. Borg \& Gall (1983) says that education research and development is a process used to develop and validate educational products. To get an assessment in accordance with its function, the researcher takes the following steps: 1) Analyzing competencies, 2) Formulation of indicators and objectives, 3) Making instrument louvers, 4) Making instrument items, 5) Validation of experts stage 1,6) 
Data analysis, 7) Revision, 8) Stage 2 expert validation, 9) Data analysis, and 10) Finalization (Djaali \& Muljono, 2008).

\section{Population and Sample}

Population is a subject or object determined by the researcher and has certain qualities and characteristics for and concluded and studied (Sugiyono, 2017). The subjects of this study were 2 people as validators, namely physics lecturers at Padang State University. As for the research object/sample is an instrument of effectiveness that measures critical thinking skills, creative thinking, communicating and collaborating; known as $4 \mathrm{C}$.

\section{Data Collection and Instrument}

The instruments used for data collection are instrument assessment sheets for critical thinking skills, creative thinking skills assessment sheet sheets, collaborative skills instrument evaluation sheets, and oral and written communication skills assessment sheet sheets, which are arranged based on aspects that will be assessed from the lattice of instruments of critical thinking, creative, collaboration, and communication that are developed.

\section{Data Analysis}

Data analysis from the validation instrument assessment sheets of critical thinking, creative, collaboration, and communication using a Likert Scale. The Likert scale used is (1) very less, (2) less, (3) sufficient, and (4) good, and 5) very good.

$V=\frac{\sum s}{[n(c-1)]}$

For validity categories based on the Aiken's V formula.

Where :

$\mathrm{s}=\mathrm{r}-\mathrm{lo}$

Information :

lo $=$ lowest validity rating number

$\mathrm{c}=$ highest validity rating number

$\mathrm{r}=$ the number given by the validator

$\mathrm{n}$ = validator's number below.

Whereas the validity category according to Azwar (2015) is shown in Table 1

Table 1. Categories of Validity

\begin{tabular}{cc}
\hline Value & Criteria \\
\hline$\geq 0,6$ & Valid \\
$<0,6$ & Invalid \\
\hline
\end{tabular}

This validity uses the Aiken's V formula which divides the categories of validity into valid and invalid. The instrument is said to be valid when spaced $\geq 0,6$. 


\section{RESULT AND DISCUSSION}

The instrument developed in this study was a lattice of instruments of critical thinking, creative, collaboration, and communication skills both oral and written. To get quality instruments, it is necessary to develop an assessment sheet for validating the skills of critical thinking, creative, collaboration, and communication both oral and written. With this instrument assessment sheet, it is found an instrument of critical thinking, creative, collaboration, and good oral and written communication so that later it can also assess the quality of the developed video.

When validating, several suggestions are given by the validator. In brief the validator suggestions are presented in Table 2 .

Table 2. Validator Suggestions Summary

\begin{tabular}{|c|c|c|}
\hline Instrument & Before Revision & After Revision \\
\hline $\begin{array}{l}\text { Critical Thinking } \\
\text { Skills Instruments }\end{array}$ & $\begin{array}{l}\text { There are overlap indicators } \\
\text { on aspects of critical thinking } \\
\text { skills with creative thinking } \\
\text { skills. }\end{array}$ & $\begin{array}{l}\text { Improve overlap } \\
\text { indicators by removing } \\
\text { indicators of critical } \\
\text { thinking skills. }\end{array}$ \\
\hline $\begin{array}{l}\text { Creative Thinking } \\
\text { Skills Instruments }\end{array}$ & $\begin{array}{l}\text { There are overlap indicators } \\
\text { on aspects of creative } \\
\text { thinking skills with critical } \\
\text { thinking skills. }\end{array}$ & \\
\hline $\begin{array}{l}\text { Collaboration Skills } \\
\text { Instruments }\end{array}$ & $\begin{array}{l}\text { 1. Make a collaboration } \\
\text { skills assessment for each } \\
\text { student } \\
\text { 2. Design a scoring rubric } \\
\text { that is easy to measure for } \\
\text { each student }\end{array}$ & $\begin{array}{l}\text { 1. Make a collaboration } \\
\text { skills assessment for } \\
\text { each student } \\
\text { 2. Scoring rubrics have } \\
\text { been made that are } \\
\text { easy to measure for } \\
\text { each student }\end{array}$ \\
\hline $\begin{array}{l}\text { Oral Communication } \\
\text { Skills Instruments }\end{array}$ & $\begin{array}{l}\text { 1. Clarify the meaning of } \\
\text { the sentence mostly and a } \\
\text { small part on the } \\
\text { description of indicators } \\
\text { of oral communication } \\
\text { skills } \\
\text { 2. Design an assessment of } \\
\text { oral communication skills } \\
\text { for each individual }\end{array}$ & $\begin{array}{l}\text { 1. Replace sentences } \\
\text { mostly and small parts } \\
\text { into sentences that } \\
\text { explain quantitative } \\
\text { meaningful sentences } \\
\text { 2. Design a scoring rubric } \\
\text { that is easy to measure } \\
\text { for each student }\end{array}$ \\
\hline $\begin{array}{l}\text { Writing } \\
\text { Communication } \\
\text { Skills Instruments }\end{array}$ & $\begin{array}{l}\text { 1. Explain the work of } \\
\text { students what will be } \\
\text { assessed on the written } \\
\text { communication skills } \\
\text { instrument } \\
\text { 2. Make an assessment of } \\
\text { written communication }\end{array}$ & $\begin{array}{l}\text { 1. Explain the work of } \\
\text { students namely the } \\
\text { answers made in } \\
\text { LKPD as a learning } \\
\text { video assistant } \\
\text { 2. Make a collaboration }\end{array}$ \\
\hline
\end{tabular}


skills for each student

3. Improve sentences mostly and small parts into sentences that are easily measured and understood skills assessment for each student

3. Replacing sentences mostly and small parts into sentences that explain quantitative meaningful sentences

Based on the suggestions from the validator listed in Table 2, improvements have been made to produce instruments of critical thinking, creative, collaboration, and communication skills both oral and written that are valid and can be used to validate learning videos. The results of the validator's evaluation after making improvements to each instrument are presented in Table 3-7.

The results of validating the instruments of critical thinking skills carried out by two validators can be seen in Table 3 . The results of validating of critical thinking skills instrument carried out by two validators can be seen in Table 3 .

Table 3. Results of Validation of Critical Thinking Skills Instrument

\begin{tabular}{|c|c|c|c|c|}
\hline \multirow{2}{*}{ Aspect } & \multicolumn{2}{|c|}{ Average Rating Score } & \multirow{2}{*}{ Average } & \multirow{2}{*}{ Criteria } \\
\hline & Validator 1 & Validator 2 & & \\
\hline $\begin{array}{l}\text { Conformity with the } \\
\text { problem to be solved } \\
\text { and the objectives to } \\
\text { be achieved. }\end{array}$ & 1 & 0,75 & 0,87 & Valid \\
\hline $\begin{array}{l}\text { Clarity of } \\
\text { competencies that must } \\
\text { be met, clarity of } \\
\text { instructions for using } \\
\text { the instrument, ease of } \\
\text { instrument } \\
\text { implementation, } \\
\text { accuracy of instrument } \\
\text { assessment, and clarity } \\
\text { of instrument } \\
\text { feedback. }\end{array}$ & 0,90 & 0,83 & 0,86 & Valid \\
\hline $\begin{array}{l}\text { Instrument readability, } \\
\text { instrument display } \\
\text { quality. }\end{array}$ & 1 & 0,96 & 0,98 & Valid \\
\hline Average & & & 0,91 & Valid \\
\hline
\end{tabular}

From Table 3, it can be seen that critical thinking skills instrument is valid. This is evidenced by the average value of the critical thinking skills instrument of 0,91 . Thus critical thinking skills instrument can be used to validate the learning video to be developed. The suggestion given by the validator for this instrument is to use simple 
language in making indicator items. While the validation of creative thinking skills instrument is presented in Table 4.

Table 4. Results of Validation of Creative Thinking Skills Instrument

\begin{tabular}{|c|c|c|c|c|}
\hline \multirow[t]{2}{*}{ Aspect } & \multicolumn{2}{|c|}{ Average Rating Score } & \multirow[t]{2}{*}{ Average } & \multirow[t]{2}{*}{ Criteria } \\
\hline & Validator 1 & Validator 2 & & \\
\hline $\begin{array}{l}\text { Conformity with the } \\
\text { problem to be solved } \\
\text { and the objectives to be } \\
\text { achieved. }\end{array}$ & 1 & 0,75 & 0,87 & Valid \\
\hline $\begin{array}{l}\text { Clarity of } \\
\text { competencies that must } \\
\text { be met, clarity of } \\
\text { instructions for using } \\
\text { the instrument, ease of } \\
\text { instrument } \\
\text { implementation, } \\
\text { accuracy of instrument } \\
\text { assessment, and clarity } \\
\text { of instrument } \\
\text { feedback. }\end{array}$ & 1 & 0,85 & 0,92 & Valid \\
\hline $\begin{array}{l}\text { Instrument readability, } \\
\text { instrument display } \\
\text { quality. }\end{array}$ & 1 & 0,96 & 0,98 & Valid \\
\hline Average & & & 0,93 & Valid \\
\hline
\end{tabular}

According to Table 4 that the creative thinking skills instrument is valid. This can be seen from the average value of creative thinking skills instrument of 0,93 . Thus this creative thinking skills instrument can be used to validate the learning videos that will be developed. The advice given by the validator for this instrument is to improve the instrument indicators with clear sentences. In the following Table 5 presented a validation of collaboration skills instrument.

Table 5. Results of Validation of Collaboration Skills Instrument

\begin{tabular}{|c|c|c|c|c|}
\hline \multirow{2}{*}{ Aspect } & \multicolumn{2}{|c|}{ Average Rating Score } & \multirow{2}{*}{ Average } & \multirow{2}{*}{ Criteria } \\
\hline & Validator 1 & Validator 2 & & \\
\hline $\begin{array}{l}\text { Conformity with the } \\
\text { problem to be solved } \\
\text { and the objectives to be } \\
\text { achieved. }\end{array}$ & 1 & 1 & 1 & Valid \\
\hline $\begin{array}{l}\text { Clarity of competencies } \\
\text { that must be met, } \\
\text { clarity of instructions } \\
\text { for using the } \\
\text { instrument, ease of } \\
\text { instrument }\end{array}$ & 1 & 0,96 & 0,98 & Valid \\
\hline
\end{tabular}




implementation,
$\begin{aligned} & \text { accuracy of instrument } \\
& \text { assessment, and clarity } \\
& \text { of instrument feedback. }\end{aligned}$
$\begin{aligned} & \text { Instrument readability, } \\
& \text { instrument display } \\
& \text { quality. }\end{aligned}$
\begin{tabular}{l} 
Average \\
\hline
\end{tabular}

Table 5 states that collaboration skills instrument is valid, with an average value of 0,99 . Thus this collaboration skills instrument can be used to validate the learning videos that will be developed. The advice given by the validator for this instrument is to design an instrument that can measure the collaboration skills of each student. For validation of oral communication skills instrument are presented in Table 6 below.

Table 6. Results of Validation of Oral Communication Skills Instruments

\begin{tabular}{lcccc}
\hline \multicolumn{1}{c}{ Aspect } & $\begin{array}{c}\text { Average Rating Score } \\
\text { Validator 1 }\end{array}$ & Validator 2 & Average & Criteria \\
\hline $\begin{array}{l}\text { Conformity with the } \\
\text { problem to be solved } \\
\text { and the objectives to be } \\
\text { achieved. }\end{array}$ & 1 & 1 & 1 & Valid \\
$\begin{array}{l}\text { Clarity of competencies } \\
\text { that must be met, } \\
\text { clarity of instructions }\end{array}$ & 1 & & & \\
$\begin{array}{l}\text { for using the } \\
\text { instrument, ease of } \\
\text { instrument } \\
\text { implementation, } \\
\text { accuracy of instrument }\end{array}$ & & 0,93 & 0,96 & Valid \\
$\begin{array}{l}\text { assessment, and clarity } \\
\text { of instrument feedback. }\end{array}$ & & & & \\
$\begin{array}{l}\text { Instrument readability, } \\
\text { instrument display } \\
\text { quality. }\end{array}$ & 1 & & & \\
Average & & & & \\
\hline
\end{tabular}

Based on Table 6, it is stated that the oral communication skills instrument is valid, which is the average value of 0,98 . Thus this oral communication skills instrument can be used to validate the learning video to be developed. The suggestion given by the validator for this instrument is to design an instrument that can measure the oral communication skills of each student and use simple language in making instrument indicators. And in Table 7 is validation of written communication skills instrument. 
Table 7. Results of Validation of Writing Communication Skills Instruments

\begin{tabular}{|c|c|c|c|c|}
\hline \multirow[t]{2}{*}{ Aspect } & \multicolumn{2}{|c|}{ Average Rating Score } & \multirow[t]{2}{*}{ Average } & \multirow[t]{2}{*}{ Criteria } \\
\hline & Validator 1 & Validator 2 & & \\
\hline $\begin{array}{l}\text { Conformity with the } \\
\text { problem to be solved } \\
\text { and the objectives to be } \\
\text { achieved. }\end{array}$ & 1 & 0,75 & 0,87 & Valid \\
\hline $\begin{array}{l}\text { Clarity of competencies } \\
\text { that must be met, } \\
\text { clarity of instructions } \\
\text { for using the } \\
\text { instrument, ease of } \\
\text { instrument } \\
\text { implementation, } \\
\text { accuracy of instrument } \\
\text { assessment, and clarity } \\
\text { of instrument feedback. }\end{array}$ & 1 & 0,80 & 0,90 & Valid \\
\hline $\begin{array}{l}\text { Instrument readability, } \\
\text { instrument display } \\
\text { quality. }\end{array}$ & 1 & 0,86 & 0,93 & Valid \\
\hline Average & & & 0,90 & Valid \\
\hline
\end{tabular}

Based on Table 7, it is stated that written communication skills instrument is valid, with an average value of 0,90 . Thus this written communication skills instrument can be used to validate the learning video to be developed. The advice given by the validator for this instrument is to design an instrument that can measure the written communication skills of each student and use simple language in making instrument indicators.

Before developing contextual-based learning videos that can improve the quality of $4 \mathrm{C}$ skills of students, researchers will first create a $4 \mathrm{C}$ instrument to test video quality. If the $4 \mathrm{C}$ instrument produced is good then the video to be developed is also good, and vice versa. To produce a quality $4 \mathrm{C}$ instrument, an assessment is needed to test the quality of the instrument. This assessment is very influential on the video that will be developed. If the results of the assessment state that the quality of the 4C instrument is good then the video that will be developed to improve $4 \mathrm{C}$ skills is also of good quality.

In this study it was found that the results of the assessment of the $4 \mathrm{C}$ instrument were feasible to be developed so that the $4 \mathrm{C}$ instrument could be used to assess the learning video. By developing quality videos, it is expected that $4 \mathrm{C}$ skills of students will increase.

\section{CONCLUSION}

Based on the research results obtained that the results of validator assessment on critical thinking, creative, collaboration, and communication instruments both oral and 
written are valid, so that this effectiveness instrument can be used to validate physics learning videos based on CTL wave material developed.

\section{ACKNOWLEDGEMENTS}

Thank you to the Directorate of Research and Community Service, Directorate General of Research and Technology Strengthening Ministry of Research, Technology and Higher Education for funding this research. Thank you also to the Institute of Research and Community Service, the Head of Faculty of Mathematics and Natural Sciences, and the Chairperson of Physics Education Study Program at Padang State University for supporting this research. Thank you also go to Dr. Fatni Mufit, S.Pd, M.Si and Drs. Amali Putra, M.Pd, who has provided suggestions for improvements to this effectiveness instrument.

\section{REFERENCES}

Adib, Helen Sabera. (2017). Teknik Pengembangan Instrumen Penelitian Ilmiah di Perguruan Tinggi Keagamaan Islam. Seminar Nasional Pendidikan, Sains dan Teknologi Fakultas Matematika dan Ilmu Pengetahuan Alam Universitas Muhammadiyah Semarang. ISBN : 978-602-61599-6-0.

Andiko,P.T., Rohiat, S., \& Elvinawati. (2019). Hubungan Implementasi Contextual Teaching And Learning (CTL) Dengan Hasil Belajar Peserta didik Mata Pelajaran Kimia Di Kelas X MIA SMA Negeri 8 Kota Bengkulu. Jurnal Pendidikan dan Ilmu Kimia , 3(1):70-75. p-ISSN 2252-8075. e-ISSN 26152819.

Arif, M., Festiyed, Desnita, \& Dewi, W.S. (2019). Pembuatan Bahan Ajar Berbasis Android Untuk Pembelajaran Fisika Pada Materi Gelombang Bunyi, Gelombang Cahaya dan Alat Optik Di Kelas XI SMA/MA. Pillar of Physics Education. Vol 12. No 3, 2019, 457-464.

Arifin, Z. (2017). Kriteria Instrumen Dalam Penelitian. Jurnal THEOREMS (The Original Research of Mathematics). Vol. 2 No. 1, Juli 2017, hal. 28-36.

Aristiyaningsih \& Budiharti. (2015). Peningkatan Sikap Peka Terhadap Lingkungan Sekitar Melalui Project Based Learning. Prosiding Seminar Nasional Fisika dan Pendidikan Fisika (SNFPF) Ke-6. Volume 6 Nomor 12015 ISSN : 2302-7827.

Arsyad, Azhar. (2011). Media Pembelajaran. Jakarta : PT. Raja Grafindo Persada.

Azwar, S. (2015). Reliabilitas dan Validitas. Yogyakarta : Pustaka Belajar.

Baharuddin, I. (2014). Efektivitas Penggunaan Media Video Tutorial Sebagai Pendukung Pembelajaran Matematika Terhadap Minat Dan Hasil Belajar Peserta Didik SMA Negeri 1 Bajo Kabupaten Luwu Sulawesi Selatan. Jurnal Nalar Pendidikan, 2(2), 247-255. doi:https://doi.org/10.26858/jnp.v2i2.1974.

Borg, W.R. \& Gall, M.D. (1983). Educational Research: An Introduction. Fifth Edition. New York: Longman. 
Busyaeri, A., Udin, T., \& Zaenudin, A. (2016). Pengaruh Penggunaan Video Pembelajaran Terhadap Peningkatan Hasil Belajar Mapel IPA di MIN Kroya Cirebon. Al Ibtida: Jurnal Pendidikan Guru MI, 3(1), 116-137. Doi : http://dx.doi.org/10.24235/al.ibtida.snj.v3i1.584.

Djaali \& Muljono, P. (2008). Pengukuran Dalam Bidang Pendidikan. Jakarta : PT. Grasindo.

Festiyed. (2015). Studi Pendahuluan Implementasi Kurikulum 2013 Dalam Mengintegrasikan Pendekatan Saintifik Melalui Model Inkuiri Dan Authentic Assesment Dalam Pembelajaran IPA di Kota Padang. Semirata.

Hanafiah, N., \& Suhana, C. (2012). Konsep Strategi Pembelajaran. Bandung : Refika Aditama.

Haryadi, Sutrisno, L., \& Haratua. (2015). Implementasi Kurikulum 2013 Pada Pembelajaran Fisika Di Kelas X SMA Kemala Bhayangkari Kabupaten Kubu Raya. Jurnal Pendidikan dan Pembelajaran Khatulistiwa. Vol. 4. No. 1. E-ISSN : 2715-2723.

Khodizah, S., Irwandani, \& Kholid, I. (2019). Development of Ludo Game as Learning Media in Circular Motion. Jurnal Pembelajaran Fisika (JPF) - Pendidikan Fisika, FKIP, Universitas Lampung. Vol 7 (1), 2019, 19-28. ISSN: 2302-0105 (p); 2684-9828 (e).

Komalasari, Kokom. (2010). Pembelajaran Kontekstual : Konsep dan Aplikasi. Bandung : Refika Aditama.

Mansur, Muchlis. (2011). Pendidikan Karakter. Jakarta: Bumi Aksara.

Munir, M. 2013. Multimedia: Konsep dan Aplikasi Dalam Pendidikan. Bandung: Alfabeta.

Nurdin, dkk. (2019). Pemanfaatan Video Pembelajaran Berbasis Geogebra Untuk Meningkatkan Kemampuan Pemahaman Konsep Matematis Peserta didik SMK. Jurnal Riset Pendidikan Matematika 6 (1), 2019, 87-98.

Pertiwi, D., Suyatna, A., \& Suyanto, E. (2019). Enhancing Critical Thinking using LCDS-Based Interactive Electronic School Book in Physics. Jurnal Pembelajaran Fisika (JPF) - Pendidikan Fisika, FKIP, Universitas Lampung. Vol. 7(1), 2019, 7-18. ISSN: 2302-0105 (p); 2684-9828 (e).

Prihadi, E. (2018). Pengembangan Keterampilan 4C Melalui Metode Poster Comment Pada Mata Pelajaran PAI dan Budi Pekerti (Penelitian di SMA Negeri 26 Bandung). "Passion of the Islamic Studies Center" JPI_Rabbani.

Rakhmawati, S., Muspiroh, N., \& Azmi, N. (2016). Analisis Pelaksanaan Kurikulum 2013 Ditinjau Dari Standar Proses Dalam Pembelajaran Biologi Kelas X dI SMA Negeri 1 Krangkeng. Scientiae Educatia: Jurnal Sains dan Pendidikan Sains. Vol. 5. No. 2: 156-164.

Rusman. (2012). Model-Model Pembelajaran : Mengembangkan Profesionalisme Guru. Jakarta : Rajagrafindo Persada. 
Sugiyono. (2017). Metode Penelitian Kuantitatif, Kualitatif, dan R \& D. Bandung : Alfabeta.

Surahman, E. (2015). Pelaksanaan Kurikulum 2013 Mata Pelajaran Fisika di SMA Negeri Se Kota Tasikmalaya. Jurnal Siliwangi. Vol. 1. No.1. Nov. 2015. ISSN 2476-9312.

Tim Pengembang. (2012). Modul Pelatihan Implementasi Kurikulum 2013. Jakarta : Kementerian Pendidikan dan Kebudayaan. P. 71.

Wijaya, E.Y., Sudjimat, D.A., \& Nyoto, A. (2016). Transformasi Pendidikan Abad 21 Sebagai Tuntutan Pengembangan Sumber Daya Manusia di Era Global. Prosiding Seminar Nasional Pendidikan Matematika 2016, Universitas Kanjuruhan Malang. Volume 1 Tahun 2016 - ISSN 2528-259X.

Yulianisa, Rizal, F., Oktaviani, \& Abdullah, R. (2018). Tinjauan Keterampilan Abad 21 (21st Century Skills) dikalangan Guru Kejuruan (Studi Kasus : SMK Negeri 2 Solok). CIVED JURUSAN TEKNIK SIPIL, Vol. XX No. X, September 2018. ISSN 2302-334.

Yuniarti, N., \& Soenarto, S. (2016). Validitas Konstruk Instrumen Evaluasi Outcome Lembaga Pendidikan Guru Vokasional. Jurnal Penelitian dan Evaluasi Pendidikan, 20 (2), 221-223.

Zubaidah, Siti. (2018). Keterampilan Abad Ke-21 : Keterampilan Yang Diajarkan Melalui Pembelajaran. Seminar Nasional Pendidikan di Program Studi Pendidikan Biologi STKIP Persada Khatulistiwa Sintang - Kalimantan Barat. 